\title{
Attitudes, Rape and Law Reform in South Africa
}

\author{
Charnelle van der Bijl and Philip N. S. Rumney*
}

\begin{abstract}
In the last decade South Africa has undergone an extensive process of sexual offence law reform. This process has attempted, amongst other things, to address deficiencies in the criminal justice response to rape and has also recognised some of the limits to the impact of legal reform. These limits are partly defined by rape supportive attitudes and myths that appear to influence decision-making at all points in the criminal justice process. In South Africa, and many other jurisdictions, evidence suggests that police, prosecutorial and judicial decision-making is influenced, in part, by a range of social attitudes that misconstrue sexual violence, as well as serve to undermine the credibility of complainants. This article examines the impact of myths, social definitions of rape on rape law reform in South Africa and the points at which these reforms are likely to be undermined by social attitudes and what potentially might be done to address this problem.
\end{abstract}

Keywords Rape; Police; Law reform; Social attitudes; Legislation

In the last decade, South Africa has embarked on substantial reform of its sexual offence laws. In many respects these reforms are similar to those adopted in other jurisdictions, in that they address issues of definition, evidence and procedure. However, these reforms also exist within a particular social context. This context includes the large number of South Africans suffering from HIV and AIDS, ${ }^{1}$ the phenomenon of child and baby rape ${ }^{2}$ and the high rate of reported sexual victimisation which has been described as 'one manifestation of a very violent society' in which there is a 'general climate of tolerance towards rape'. ${ }^{3}$ This article will seek to examine several issues, but unlike other recent work in this area, will pay particular attention to the relationship between social attitudes and rape law reform. First, it will consider the extent of the problem of rape and sexual assault in South Africa. Secondly, it will examine the approach of the South African Law Reform Commission (hereinafter 'the Commission') to the question of legal reform of South African rape law, along with subsequent legislative interventions.

* University of South Africa, e-mail: Vdbijc@unisa.ac.za; University of the West of England, e-mail: phil.rumney@uwe.ac.uk. This article is based on a joint paper presented at a conference entitled 'Sexual Offences and Criminal Justice:

Challenging Myths, Supporting Victims' held at the University of the West of England (9 September 2008).

1 For discussion, see below nn. 50-67 and accompanying text.

2 For discussion of the emergence of sexual violence and baby rape as a public and political issue in South Africa, see D. Posel, 'The Scandal of Manhood: "Baby Rape" and the Politicization of Sexual Violence in Post-Apartheid South Africa' (2005) 7 Culture, Health $\theta$ Sexuality 239.

3 R. Jewkes and N. Abrahams, 'The Epidemiology of Rape and Sexual Coercion in South Africa: An Overview' (2002) 55 Social Sciences and Medicine 1231, 1238. 
Thirdly, the article will consider an issue that was explicitly acknowledged by the Commission, that is, the impact of 'social factors', ${ }^{4}$ such as social attitudes that contribute to the prevalence of rape within South African society and its impact on the enforcement of the criminal law. Finally, the article will conclude by considering the prospect of the effective enforcement of the sexual offence reforms in South Africa.

\section{The extent of rape and sexual assault in South Africa}

South Africa has a high rate of reported rape and sexual assault. In $2002 / 03$ the number of rapes recorded by the police was 52,425 , in $2003 / 04,52,733$, and 55,114, in 2004/05, 54,926 in 2005/06, and in $2006 / 07,52,617 .{ }^{5}$ Given the population of South Africa is 47 million $^{6}$ these reporting rates per head of population are high. In England and Wales, with a higher population that South Africa, ${ }^{7}$ the number of recorded rapes is significantly lower. For example, in 2006/07 there were 13,774 offences of rape recorded by the police. ${ }^{8}$ As in other jurisdictions, a large proportion of rapes in South Africa are not reported to the police. Jewkes and Abrahams report that in a South African Demographic and Health Survey report from 1999, that only 15.2 per cent of women who had ever been physically forced to have sex reported their experience to the police. ${ }^{9}$ More encouraging are statistics from the International Crime Victim Survey in Thirteen African Countries 2006, which reveals a reporting rate of 39.7 per cent. ${ }^{10}$

Victimisation surveys find a range of prevalence and incidence estimates for rape and sexual assault. These estimates vary between studies, resulting from differing sample sizes, methodologies and definitions of sexual violence. Jewkes and Abrahams cite three studies that found 6.3 per cent of women admitting to being a victim of rape across three provinces; ${ }^{11}$ with two other studies suggesting between 1.7 and 7 per cent of female participants reporting a rape in the previous five years. ${ }^{12}$ A recent study examined the sexual abuse of boys and found that victimisation rates were very high. Of 13,915 males aged 10-19 years it

4 See below n. 34 and accompanying text.

5 See also $h t t p: / / w w w . s a p s . g o v . z a /$ statistics/reports/crimestats/2007/crime_stats.htm, accessed 3 August 2009.

6 See http://www.southafrica.info/about/people/population.htm, accessed 3 August 2009.

7 The 2001 national census gave a figure of more than 52 million people resident in England and Wales: http://www.statistics.gov.uk/census2001/pyramids/pages/727.asp, accessed 3 August 2009.

8 S. Nicholas, C. Kershaw and A. Walker, Crime in England and Wales 2006/07 (Home Office: 2007) 36.

9 Above n. 3 at 1236. Jewkes and Abrahams note: '25\% of women raped in the previous year had reported it to the police and $11 \%$ of women who experienced an attempted rape'.

10 C. M. B. Naudé, J. H. Prinsloo and A. Ladikos, Experiences of Crime in Thirteen African Countries: Results from the International Crime Victim Survey. Electronic Publication, Turin, UNICRI-UNODC, 2006, 49.

11 This figure is an average of the three province rates.

12 Above n. 3 at 1237. Some of the variations in estimates may be explained by the adoption of narrow definitions of rape that explicitly refer to force, threats or being 'held down or hurt'. 
was found that 9 per cent claimed to have been a victim of 'forced sex' ${ }^{\prime 3}$ in the previous year. Of those aged 18 years at the time of the survey 44 per cent claimed to have been a victim of forced sex at some point in their lives. ${ }^{14}$ Further, in research that asked men about their sexual offending, Jewkes et al. surveyed 1,370 males aged 15-26 from 70 villages in Eastern Cape Province. ${ }^{15}$ Of these males, 16.3 per cent disclosed that they had raped a non-partner or had engaged in 'streamlining', which is a form of gang rape and 8.4 per cent reported that they had raped an intimate partner. A further 7.5 per cent admitted to attempting to rape a non-partner. ${ }^{16}$ One of the most disturbing aspects of the widespread problem of sexual violence in South Africa is the rape of children. A CIETafrica report suggests that 40 per cent of reported rapes involve child victims. ${ }^{17}$ In addition to the high rates of victimisation in South Africa, very few reports result in conviction. In a CIETafrica study of 394 women that were raped, 272 reported the rape, five cases were referred by the police to the court and only one conviction ensued. ${ }^{18}$

\section{Legal and social responses to rape in South Africa}

\section{(a) The process of rape law reform}

The enactment of the Criminal Law (Sexual Offences and Related Matters) Amendment Act 32 of 2007 (hereinafter the '2007 Act') represents a detailed reform of the substantive legal rules relating to sexual offences in South Africa and is the culmination of a law reform process taking a decade to complete. It began life as a proposed Bill on Sexual Offences which was first introduced in 1999 by the Commission. ${ }^{19}$ A number of Working Papers attempted to refine the initial proposed definition of 1999 with amendments to the proposed Bill suggested in the Working Papers of 2002, 2004 and 2006. The Sexual Offences Bill was reformulated as the Draft Criminal Law (Sexual Offences) Amendment Bill 50 of 2003 and was yet again revised in 2004 and 2006.

The resultant 2007 Act has made significant changes to the law of rape in South Africa. Prior to the Act, rape was formally defined in terms

13 A question that arises in this study is how 'forced sex' is to be interpreted by the research participants. The researchers state: "The pilot questionnaire used "rape" or its equivalent in three languages, and a variety of phrases in other languages, intended to communicate the same meaning'.

14 N. Anderson and A. Ho-Foster, '13,915 Reasons for Equity in Sexual Offences Legislation: A National School-Based Survey in South Africa' (2008) 20 International Journal for Equity in Health. This article can be accessed online at http://www.equity healthj.com/content/7/1/20.

15 R Jewkes, K. L. Dunkle and M. Nduna, 'Rape Perpetration by Young, Rural South African Men: Prevalence, Patterns and Risk Factors,' (2006) 63 Social Sciences and Medicine 2949.

16 Ibid. at 2952-3.

17 CIETafrica Executive Summary: 1997-2000, Surveys on Sexual Violence, 'Beyond Victims and Villains: South Johannesburg, 1997-2000' 5, http://www.ciet.org, accessed 3 August 2009.

18 L. Artz and D. Smythe, 'Case Attrition in Rape Cases: A Comparative Analysis' (2007) 20 SAJCJ 158, 170. See also L. Artz and D. Smythe, 'Losing ground? Making Sense of Attrition in Rape Cases' SA Crime Quarterly No. 22, December 2007, 13.

19 South Africa Law Commission, Discussion Paper 85 of 1999. 
of the common law as consisting of a male having sexual intercourse with a female without her consent. ${ }^{20}$ Although the South African law pertaining to rape has its roots in Roman-Dutch law, it has undergone subsequent revision, due to English law influence. ${ }^{21}$ Unlike the RomanDutch crime of rape, which required violence as an element of the crime, South African law, which followed the English law in this regard, did not require violence. ${ }^{22}$ It required lack of consent as the essential element. ${ }^{23}$ The proposed Bill on Sexual Offences was first introduced in 1999 by the South African Law Commission (prior to its name change to the 'South African Law Reform Commission' in 2002). ${ }^{24}$ The Commission initially suggested that lack of consent be replaced with the term 'coercive circumstances'. ${ }^{25}$ The reason furnished by the Commission for replacing the consent criterion was that: 'A shift from the "absence of consent" to "coercion" represents a shift of focus of the utmost importance from the subjective state of mind of the victim to the imbalance of power between the parties on the occasion in question' ${ }^{26}$ It is evident that the Commission wanted the focus to be on the circumstances of the sexual encounter rather than the consent of the victim. ${ }^{27}$ However, the definition of rape as set out in the 2007 Act currently refers to consent as being 'voluntary or uncoerced agreement' and therefore contains elements of both consent and coercion. In addition, the South African common law definition of rape which made reference to sexual intercourse has been amended and now refers to a widened notion of sexual penetration.

20 C. R. Snyman, Criminal Law, 5th edn (LexisNexis: Durban, 2008) 355-6. The definition of rape was narrow and only incorporated the penetration of a penis into a vagina.

21 W. A. Joubert (2004) LAWSA 253. See J. M. T. Labuschagne. 'Regterlike Misdaadskepping: Is die Engelsregterlike Benadering Versoenbaar met die Sekerheidseis van die Strafreg?' (1994) 15 Obiter 124, 128. See also S v Von Mollendorff 1987 l SA 135 (T) where it is evident that South African law does not follow English law blindly.

22 See $R$ v $K 19583$ SA 420 (A) on 423 B-C. See further $R$ v $C 19524$ SA 117 (O). In the Roman-European Law, sexual intercourse was not a requirement for rape. The focus was rather on the act of violence used by the accused to have sexual intercourse with the victim. See discussion in J. M. T. Labuschagne, 'NieKonsensuele Geslagsmisdade: 'n Misdaadsistematiese Herwaardering' (1981) 44 THRHR 18, 21 et seq.; see further Joubert, above n. 21 at 253; J. Burchell and J. Milton, Principles of Criminal Law, 3rd edn (Juta: Durban, 2005 revised 2008) at 702-3; J. M. T. Labuschagne, 'Die Penetrasie Vereiste by Verkragting Heroorweeg' (1991) 108 South African Law Journal 148 and J. M. T. Labuschagne, 'Verkragting in die Inheemse Reg' (1994) 15 Obiter 85-8ff. for discussion of a different approach followed in South African customary law.

23 S v Ncanywa 1992 1 SACR 209 (Ck) on 212 A-E; Labuschagne (1991), above n. 22 at 148-50; Snyman, above n. 20 at 355; Criminal Law (Sexual Offences and Related Matters) Amendment Act 32 of 2007, ss 1, 3 and 5.

24 SALC Discussion Paper 85 of 1999.

25 Clause 2 of the Sexual Offences Bill of 1999 was the first attempt to move away from the consent criterion in the definitional elements and the issue of consent was replaced with the concept of coercive circumstances. See S. E. van der Merwe, 'Redefining Rape: Does the Law Commission Really Wish to Introduce a Reverse Onus?' (2001) 14 SACJ 60 on 61. See also S v Steenberg 19793 SA 513 (B) 517H518A.

26 SALC Discussion Paper 85 of 1999, 114.

27 See also, in general, J. Milton, 'Re-defining the Crime of Rape: The Law Commission's Proposals' (1999) 12 SACJ 364, 368. 
Section 3 of the 2007 Act defines rape as follows:

Any person ('A') who unlawfully and intentionally commits an act of sexual penetration with a complainant (' $\mathrm{B}$ '), without the consent of $\mathrm{B}$, is guilty of the offence of rape.

Sexual penetration is defined widely in s. 1 as including:

any act which causes penetration to any extent whatsoever by-

(a) the genital organs of one person into or beyond the genital organs, anus, or mouth of another person;

(b) any other part of the body of one person or, any object, including any part of the body of an animal, into or beyond the genital organs or anus of another person; or

(c) the genital organs of an animal, into or beyond the mouth of another person,

'consent' means voluntary or uncoerced agreement.

\section{(b) Rape reform and 'social factors'}

The work of the Commission and the provisions of the subsequent Act recognise, to various degrees, a fundamental issue in reform of sexual offence laws: there is a significant difference between enacting new laws and the effective enforcement of those laws. Across numerous jurisdictions one of the weaknesses of law reform recommendations in the context of rape and sexual assault has been the exclusive focus on legal rules that define offences or govern procedures, while ignoring many of the factors that impact on the enforcement of the criminal law. ${ }^{28}$ Indeed, what is evident from four decades of research into the impact of rape law reform is that reform measures have often not fully met their objectives of improving reporting rates, as well as improving the treatment of complainants within the legal process. ${ }^{29}$ This has led one commentator to argue that in the past those who have favoured rape law reform 'may have oversimplified the problem and the solution'. ${ }^{30}$ This section will proceed by examining the ways in which the Commission and Parliament in South Africa have taken a somewhat wider approach to the law reform process, than is the case in many other jurisdictions.

The primary, though not exclusive, focus of the reform process that led to the 2007 Act was the revision of black-letter legal rules. This is unsurprising given the objectives of the Commission, as set out in s. 4 of the South African Law Commission Act 19 of 1973, which are inter alia to 'make recommendations for the development, improvement, modernization or reform' of laws. This is very much a conventional focus for the work of law reform bodies in many parts of the world. Interestingly, however, in its report, the Commission also looked beyond this traditional remit. The Commission report made a series of non-

28 For example, see the examination of rape law reform in England and the limits of 'black-letter' reform proposals: P. Rumney, 'The Review of Sex Offences and Rape Law Reform: Another False Dawn?' [2001] 64 MLR 890; J. Temkin and B. Kraché, Sexual Assault and the Justice Gap: A Question of Attitude (Hart: Oxford, 2007).

29 S. J. Schulhofer, Unwanted Sex: The Culture of Intimidation and the Failure of the Law (Harvard University Press: 2000).

30 K. Bumiller, 'Rape as a Legal Symbol: An Essay on Sexual Violence and Racism' (1987) 42 University of Miami Law Review 75, 84. 
legislative recommendations relating to such issues as the treatment of sex offenders ${ }^{31}$ and of medical issues and care for victims, keeping victims informed about decision-making, training of legal and medical personnel and the use of such things as intermediaries and anatomical dolls to assist in the investigative process. ${ }^{32}$ The Commission also made recommendations to various government departments, including the departments of Health, Education and Correctional Services and Social Welfare Services. ${ }^{33}$ The breadth of recommendations by a law reform body is unusual and was recognition of the need for a range of legal and extra-legal measures to assist in the successful enforcement of the criminal law in South Africa. Indeed, in its report the Commission explicitly recognised the importance of taking a wider perspective in law reform:

The report purposely contains innovative and progressive recommendations regarding changes to the criminal justice system. The intention is to encourage victims of sexual violence to approach the system for assistance and to improve the experiences of those victims who choose to enter the criminal justice system, whilst at the same time giving due regard to the rights accorded to alleged perpetrators of sexual offences. Also included in the report are recommendations that are non-legislative in nature. These recommendations deal with some of the difficulties encountered by victims of sexual violence and some of the social factors contributing to the high incidence of sexual offences. Although this falls outside the narrow scope of law reform, this investigation's extended terms of reference are explicit in this regard. It is hoped that in so doing, action by the appropriate government structures will be encouraged and that communities will be galvanised to participate in the fight against this form of violence. ${ }^{34}$

The Commission was also mindful of particular contextual issues facing South African society, such as limited financial resources. It noted that: 'Proposals that require substantial additional resources are unlikely to be viable in the current economic climate. Therefore the main focus should be on identifying ways in which existing agencies and processes can be made to work more effectively' ${ }^{35}$

The widened nature of reform in South Africa is not limited to the recommendations of the South African Law Reform Commission; it extends to the text of the 2007 Act itself. Provision is made for the rights of victims in the form of compulsory medical testing of offenders as well as the provision of the post-exposure prophylaxis treatment (s. 28), a national register for sex offenders (ss 40-53) and a duty to report sexual offences against children (s. 54). Furthermore, no inferences may be drawn if there is a delay in reporting (s. 59) and the evidence of a sexual offence complainant may not be treated with caution merely as a result

31 These recommendations included the use of legal orders to control sex offenders in the community, as well as treatment issues and public notification of the whereabouts of convicted sex offenders: South African Law Commission, Sexual Offences Report: Project 107 (2002) 249-53, 361-3, 367-8.

32 Ibid. at 324-49.

33 Ibid. at 349-76.

34 Ibid. at para. 2.1.

35 Ibid. at para. 1.3. See also para. 1.4 for similar comments. 
of the nature of the offence (s. 60). A National Policy Framework provides for uniformity in dealing with sexual offences and for enhancing the delivery of services (s. 62). The preamble of the Act also states inter alia:

... the prevalence of the commission of sexual offences in our society is primarily a social phenomenon, which is reflective of deep-seated, systemic dysfunctionality in our society, and that legal mechanisms to address this social phenomenon are limited and are reactive in nature, but nonetheless necessary;

... the South African common law and statutory law do not deal adequately, effectively and in a non-discriminatory manner with many aspects relating to or associated with the commission of sexual offences, and a uniform and coordinated approach to the implementation of and service delivery in terms of the laws relating to sexual offences is not consistently evident in Government; and thereby which, in too many instances, fails to provide adequate and effective protection to the victims of sexual offences thereby exacerbating their plight through secondary victimization and dramatization ...

This acknowledgement goes much further than merely highlighting the limitations of an outdated legal code, it is a recognition of institutional failure in enforcing the criminal law and of 'dysfunctional' societal values and attitudes that, as the next section will indicate, are deeply engrained within South African society. While the acknowledgement of deeply engrained social attitudes and its link to sexual violence may in itself have little practical impact, it will be interesting to see to what extent, if any, the South African courts take the contents of the preamble into account when interpreting the 2007 Act.

\section{(c) General attitudes to rape in South Africa}

Myths and stereotyping have long been blamed for the denial of many instances of non-consensual sex as rape and as a cause of underreporting amongst victims. ${ }^{36}$ In a survey by CIETafrica, which looked at sexual violence occurring in Southern Johannesburg, a number of questions were asked of the men interviewed who replied as follows:

Do women say 'yes' when they say 'no'? One in four men held the belief that this is indeed the case.

Have you had sex with a woman without her consent? One in five men said they had in fact done this.

Who causes sexual violence? Two-thirds of the men interviewed said that women were partly to blame for rape. ${ }^{37}$

Jewkes has observed two characteristics of sexual offending in South Africa which suggest the existence of societal attitudes which tolerate or even encourage sexual offending. First, 'Parents, families and society put

36 M. R. Burt, 'Rape Myths' in M. E. Odem and J. Clay-Warner, Confronting Rape and Sexual Assault (Rowman \& Littlefield: 1997) 129, 131.

37 CIETafrica, Executive Summary: 1997-2000 Surveys on Sexual Violence, Beyond Victims and Villains: South Johannesburg, 1997-2000, 2-3, http://www.ciet.org, accessed 3 August 2009. 
little social pressure on men and boys to discourage them from perpetrating rape. The onus of preventing rape is placed on women, and they are usually blamed for provoking the incident ${ }^{\prime}{ }^{38}$ Secondly, the use of coercion, including violence by males is tolerated unless it breaks certain cultural norms, for example, where the victim 'has a higher social standing'. In other circumstances, Jewkes argues that 'young men are "allowed" to do anything they can get away with'. ${ }^{39}$ Other research has shown that, to varying degrees, young men and women in South Africa make distinctions between rape and 'rough sex' ${ }^{40}$ Incidents of rape are minimised or downplayed, particularly when they take place in existing relationships where sex becomes seen as an obligation. ${ }^{41}$ These factors combined to provide for a 'significantly narrower referential field than its legal or technical English meaning' ${ }^{42}$ Wood et al. note the contours of the social definition of rape found in their research, which excluded incidents of 'rough sex':

Popular understandings of the category of rape were largely incommensurate with legal definitions, with rape popularly defined as a violent sexual act committed by a man who is not a sexual partner and with whom there is no prior sexual 'contract.' Where sexual coercion in terms of the category of forced sex by a sexual partner is concerned, the intimate nature of the woman's relationship with the man, the implicit and assumed sexual contract between them, and the stigma and shame attached to having been raped explain why many young women reconfigure-or accept their partner's reconfiguring of-sexual coercion by a partner as 'not rape'. ${ }^{43}$

Wood et al. also found evidence that some women are said to invite rape', as a result of their conduct which breaks accepted boundaries of female behaviour, such as being intoxicated. In these circumstances women shoulder the burden of blame and responsibility:

The harm caused to rape survivors was further bound up with female reputation. On the one hand, rape could potentially (but often did not) configure reputations, bringing about a literal cheapening of female bodies. On the other hand, rape might also be linked to a priori shame or 'dirtiness.' Ideas linking rape with ihlazo (disgrace) traced the contours of blame through the implication that women might invite rape through their behavior. This notion was particularly applied by elders and young men to girls and young women perceived to be behaving in ways that challenged ideals of proper femininity, including having sex with too many partners, getting drunk, and dressing provocatively. Such women-symbolized in

38 R. Jewkes, 'Non-consensual Sex among South African Youth: Presence of Coerced Sex and Discourses of Control and Desire' in S. J. Jejeebhoy, I. Shah and S. Thapa (eds), Sex without Consent: Young People in Developing Countries (Macmillan: 2005) 93.

39 Ibid.

40 K. Wood, H. Lambert and R. Jewkes, "Showing Roughness in a Beautiful Way": Talk about Love, Coercion, and Rape in South African Youth Sexual Culture' (2007) 21 Medical Anthropology Quarterly 277.

41 Ibid.

42 Ibid. at 297.

43 Ibid. at 296. 
people's imaginations by girls who hung out in shebeens-were thought to be signalling their sexual availability. ${ }^{44}$

These attitudes are highly significant because there is an abundance of evidence from other jurisdictions which suggests that attitudes towards female rape victims who behave 'inappropriately' are widespread and undermine the enforcement of the criminal law. In a review of literature on attitudes to rape, Ward notes that in cases involving intoxication: 'People are ... more likely to see intoxication as contributing to the woman's responsibility in sexual assault' ${ }^{45}$ In order to establish whether such attitudes actually influence juror decision-making several studies have examined the effect of complainant intoxication on rape juries. Early research from the USA found that '[rape] jurors were influenced by a victim's "character". They were less likely to believe in a defendant's guilt when the victim had reportedly . . d drank or used drugs . ..${ }^{46}$ It was also found that jurors were likely to take into account a bewildering array of complainant character traits, 'carelessness' and the extent to which her 'gender role behaviour' departed from that expected of a woman. ${ }^{47}$ Similarly, in a ground-breaking recent study, ${ }^{48}$ Finch and Munro used trial re-enactments with mock jurors to examine attitudes and decision-making in the context of an alleged rape involving an intoxicated complainant. They found that some mock jurors: 'tapped into highly dubious, but widely supported, social conventions which indicate that women who drink or flirt with men, or who take steps to initiate some intimacy, cannot complain when men take this behaviour to imply a willingness to engage in intercourse thereafter' ${ }^{49}$

\section{(d) Myths, rape and HIV or other life-threatening illnesses}

The Commission has stated that although no statistics are available relating to the risk of HIV transmission during rape and sexual assault, it is of the view that the prevalence of HIV is increased by sexual violence, especially as statistics reveal that sexual transmission accounts for at least 80 per cent of HIV transmission in South Africa. ${ }^{50}$ The prevalence of HIV infection in South Africa is reaching epidemic proportions which may to some extent be attributed to the high incidence of rape and societal myths associated with HIV and AIDS. A number of traditional

44 Above n. 41 at 295. See also J. Wojcicki, "'She Drank His Money": Survival Sex and the Problem of Violence in Taverns in Gauteng Province, South Africa' (2002) 16 Medical Anthropology Quarterly 267, 295.

45 C. A. Ward, Attitudes toward Rape: Feminist and Psychological Perspectives (Sage Publications: London, 1995) 76.

46 G. LaFree et al., 'Jurors' Responses to Victims' Behavior and Legal Issues in Sexual Assault Trials' (1985) 32 Social Problems 389, 397. See also H. Kalven and H. Zeisel, The American Jury (Little Brown: Boston, 1966) ch. 17.

47 LaFree et al., above n. 46. For a more detailed analysis of juror decision-making in rape cases, see G. D. LaFree, Rape and Criminal Justice: The Social Construction of Sexual Assault (Wadsworth: Belmont, 1989).

48 E. Finch and V. E. Munro, 'Breaking Boundaries? Sexual Consent in the Jury Room' (2006) 26 Legal Studies 303.

49 Ibid. at 318

50 South African Law Commission, Fourth Interim Report on Aspects of the Law Relating to AIDS (2000) 13-14. 
beliefs exist which contribute to the growing spread of the virus and research suggests that such beliefs are widespread. ${ }^{51}$ Many heterosexual men are of the view that they cannot be infected with the HIV virus, whilst others believe that an HIV-positive man who has sexual intercourse with a virgin will be cured. ${ }^{52}$ HIV/AIDS is furthermore linked to witchcraft in traditional customary society and is a witchdoctor's curse known as ilumbo or lilamba which can be cured by traditional remedies. ${ }^{53}$ In a study of 100 Zulu-speaking youth conducted in Kwa-Zulu Natal it was found that there is a propensity for HIV-infected youth to expose their partners to the HIV virus deliberately during consensual intercourse. ${ }^{54}$ One 25 -year-old waiter who was interviewed stated:

You lose hope. You know you will be rejected, you know you're going to die. All you can do is go off and spread it. It's your only hope knowing that you won't die alone. It's the one thing you have to lean on really. ${ }^{55}$

Women in traditional societies may be especially vulnerable to HIV infection. This phenomenon can be attributed to their lack of independence and power in a traditional society where rape is a matter which was settled outside the criminal justice system. ${ }^{56}$ If one bears in mind that a number of victims of rape are party to customary marriages, the situation is complicated. This might be the case where victims of marital rape in customary law for instance, may not believe that a crime has been perpetrated against them. ${ }^{57}$ The problem of HIV transmission is compounded in customary law as women are viewed as being part of a patriarchal society where reproductive capacity is a legal object. ${ }^{58}$ Pieterse states:

Because procreation is not possible if a condom is used, sex in an African marriage is almost always unprotected. Women are too afraid to ask their husbands to use condoms and those who do are often violently accused of cheating. ${ }^{59}$

51 See 'Myths and Misconceptions about Aids', available at http://www.journaids.org/ myths.php, accessed 3 August 2009. Some myths include: Having sex with a virgin will cure one of HIV/AIDS; taking vitamins or immune boosters is a cure for AIDS; HIV/AIDS is bad in Africa because Africans are hypersexual and HIV does not cause AIDS.

52 M. Pieterse, 'Beyond the Reach of Law? HIV, African Culture and the Customary Law' $^{\prime}$ (2000) 3 TSAR 428. South African Law Commission, Fourth Interim Report on Aspects of the Law Relating to AIDS (2000) 10. See further S. Leclerc-Madlala, Crime in an Epidemic: The Case of Rape and AIDS (1996) 9(2) Acta Criminologica 35-6.

53 Pieterse, above n. 52 at $428,436$.

54 Leclerc-Madlala, above n. 52 at 31 et seq.

55 Ibid. at 32 . See further ibid. at 35 where the myth relating to child virgins and the HIV virus is discussed. This myth propagates that by having sexual intercourse with a child virgin one will rid oneself of the HIV virus by providing an infusion of clean blood.

56 South African Law Commission, Fourth Interim Report on Aspects of the Law Relating to AIDS (2000) 6 and 9. See further Pieterse, above n. 52 at 436.

57 This means that the perpetrator would escape the provisions of s. 51 of the Criminal Law Amendment Act 105 of 1997 which provides for life imprisonment where the perpetrator knows of his HIV-infected status and commits a rape.

58 Pieterse, above n. 52 at 435.

59 Ibid. at 437. 
It is not hard to imagine the effect of this on the spread of HIV where the one party fails to disclose his or her HIV-infected status during unprotected consensual intercourse. The transmission of HIV therefore not only has social and juridical implications with regard to individuals, but also communities. This is especially the case with regard to customary law, its cultural beliefs and polygyny. ${ }^{60}$

In the Working Paper of 2004 there was an attempt to address the transmission of HIV by making non-disclosure of HIV/AIDS a criminal offence. ${ }^{61}$ Clause 5 in Bill 50 of 2003 as amended in 2004 stated that:

5(1) A person (A) who engages in intimate contact with another person (B) and who intentionally does not disclose to B that he or she has HIV or AIDS is guilty of an offence of criminal non-disclosure of HIV or AIDS.

What is perhaps noteworthy is that inclusion of deliberate infection of a person during sexual intercourse was originally included within the definition of rape, but this was later removed from the 2007 Act. Several reasons were cited for this. It was argued that given the law of rape prohibits non-consensual sexual activity, it should not be extended to cover consensual activities which involve the transmission of disease. ${ }^{62}$ Further, it was argued that South African women have the highest prevalence rate for HIV and that a failure to disclose their HIV status would only increase discrimination against such women. ${ }^{63}$ This can be illustrated with reference to the model below on prevalence rates which was released by the Actuarial Society of South Africa.

Table 1. ASSA2003 Model projections: raw data ${ }^{64}$

\begin{tabular}{lllll}
\hline Prevalence rates & 2006 & 2007 & 2010 & 2015 \\
\hline Antenatal clinics & $28.3 \%$ & $28.7 \%$ & $29.2 \%$ & $29.1 \%$ \\
Youth aged 15-24 & $10.4 \%$ & $10.4 \%$ & $10.5 \%$ & $10.4 \%$ \\
Male population & $10.1 \%$ & $10.2 \%$ & $10.5 \%$ & $10.7 \%$ \\
Female population & $12.3 \%$ & $12.6 \%$ & $13.1 \%$ & $13.2 \%$ \\
Total population & $11.2 \%$ & $11.4 \%$ & $11.8 \%$ & $12.0 \%$ \\
\hline
\end{tabular}

As things stand, the 2007 Act does not provide for a specific offence relating to the deliberate infection with the HIV virus or other lifethreatening illnesses on the basis that such conduct can be prosecuted

60 Above n. 59 at 431.

61 Clause 5. See also cl. 6(1) which provides for an offence where there is criminal non-disclosure of a sexually transmissible infection other than HIV.

62 S. Chisala, 'Rape and HIV/AIDS: Who's Protecting Whom?' in L. Artz and D. Smythe, Should We Consent? Rape Law Reform in South Africa (Juta: Cape Town, 2008) 59-61.

63 See comments by Judge Cameron in the SALC Report on Sexual Offences Project 107 of 2002 at 34. See further Burchell and Milton, above n. 22 at 725.

64 In November 2005, the Actuarial Society of South Africa (ASSA) released the ASSA2003 model projects AIDS infection, mortality and a range of other indicators. See 'HIV/ AIDS statistics', available at http://www.journaids.org/statistics, accessed 3 August 2009. 
under existing common law crimes. ${ }^{65}$ In terms of the South African common law, for criminal liability to ensue, the State must prove beyond a reasonable doubt that an unlawful voluntary act or omission was committed, accompanied by fault and criminal capacity. If all the elements are present, a conviction can possibly be secured under the common law crimes of murder, culpable homicide, assault with intent to cause grievous bodily harm and attempt to commit these offences. ${ }^{66}$ There is nevertheless a body of scholarly opinion which suggests that the deliberate infection of another person with a life-threatening illness should be regarded as rape ${ }^{67}$ However, the Act does provide in ss $27-34$ of Chap. 5 for the testing of offenders and makes provision for services for victims relating to post-exposure prophylaxis treatment.

\section{(e) Attitudes, 'bureaucratic routines' 68 and law enforcement}

Measuring the impact of legal reform is a complex affair, but as noted earlier, ${ }^{69}$ evidence suggests that rape law reform has only had a limited impact on the operation of the criminal justice system. Substantive reform of the criminal law, along with procedural and evidential rules, is only one means of affecting change in the legal process. Legal rules operate within a system of law enforcement agencies, work-based cultures and practices. Research suggests that there can be many factors influencing how criminal cases are dealt with by the justice system and there can be significant variations between jurisdictions. ${ }^{70}$ However, one significant influence on criminal justice decision-making is social attitudes. It is well established in the literature that many people share 'prejudicial, stereotyped and inaccurate perceptions of sexual violence $e^{71}$

65 Chisala, above n. 62.

66 See Burchell and Milton, above n. 62 at 138.

67 Ibid. at 711 . See further Snyman, above n. 20 at 366; W. Schomburg and I.

Peterson, 'Genuine Consent to Sexual Violence under International Criminal Law' (2007) 101 Am J Int'l L 121, 126-7 where they state: 'In particular during the conflict in Rwanda, individuals were also subjected to conduct such as deliberate infection with the AIDS virus and the insertion of sharp objects into their genitals. The ICTR has correctly held that the latter may constitute rape. Acts of this kind have usually caused serious bodily injuries and even led to the death of the victim. They can hardly be conceived of "merely" as undesired sex.'

68 See below n. 75 and accompanying text.

69 See above n. 29 and accompanying text.

70 This makes direct comparisons between jurisdictions difficult. However, as our understanding of the success and limitations of rape law reform has grown over the last four decades, certain patterns have emerged which are of relevance to the South African experience.

71 C. A. Ward, Attitudes toward Rape: Feminist and Social Psychological Perspectives (Sage Publications: London, 1995) 38; Burt, above n. 36 at 130-5. There are four main classifications of rape myths namely 'nothing happened'; 'no harm was done'; 'she wanted it' and 'she deserved it'. In the category 'nothing happened', the incident is denied. It stems from previous eras where people believed that accusations of rape were used to cover up incidences of pregnancy out of wedlock or used as a motive for revenge for being jilted. The myth 'no harm was done' entails that the nature of rape as being a forced and violent act is denied, and is furthermore equated with other voluntary acts of intercourse. Traditionally, the proprietary rights of fathers and husbands were regarded as infringed by the crime of rape. This myth affected many women, who were regarded as having been devalued by the crime of rape. The myth 'she wanted it' implies that the victim is solely to blame and that the act of rape was deserved as the attacker was encouraged, or the victim wanted it. 
and that such perceptions are shared to varying degrees by men and women, and even children. ${ }^{72}$ Police, prosecutorial, judicial and jury decision-making appears to be influenced, at least in part, by a range of negative social attitudes, myths and stereotypes. ${ }^{73}$ Temkin and Kraché have recently engaged in a detailed analysis of the impact of social attitudes on rape law enforcement and argue that the treatment of rape cases by the criminal justice system relies upon:

stereotypical beliefs about rape which contain a restrictive and inaccurate understanding of what 'real rape' is. By reducing the range of what is considered a genuine rape complaint, these stereotypes are a contributory factor in the justice gap. Rape stereotypes affect the judgments made by individuals dealing with rape cases, for example as police officers, judges or members of a jury, and thereby shape the understanding of rape as it is represented and dealt with in the criminal justice system. ${ }^{74}$

Thus social attitudes can be seen as a thread running through the criminal justice system response to rape. The same negative attitudes and myths found in studies of social attitudes to rape are also found within every stage of the criminal justice process. Such beliefs can also translate into particular work-based cultures and so-called 'bureaucratic routines'. In their analysis of the effects of rape law reform in the US state of Michigan, Marsh et al. noted: 'there are junctures in the investigation at which the rape victim confronts a unique skepticism in the form of institutionalized policies and practices the law did not address. These reflect both enduring myths about the crime and unchallenged bureaucratic routines' ${ }^{75}$ In a study of the impact of rape law reform on reporting, conviction and indictment rates in six US states, Spohn and Horney found that '[I]n most of the jurisdictions we studied, the reforms had no impact ... We found like many others who have studied reforms aimed at the court system, that the rape law reforms placed few constraints on the tremendous discretion exercised by the decision makers in the criminal justice system' ${ }^{76}$ A similar point was made in the UK government's 'stocktake' of the workings of the Sexual Offences Act 2003, which like the South African reform, was a major revision of sexual offences law in England and Wales. In the 'stocktake,' one prosecutor, noted: 'legal changes need to be combined with public education on the sociological stereotypes and myths surrounding rape

Another notion attached to this myth is the physical resistance factor. If it was considered that insufficient resistance was applied, the belief was that she must have 'wanted' it. The myth that 'she deserved it' entails that the victim must have been responsible for the incident. The blame is thus placed on the victim for causing her demise.

72 For example, see S. Burton, J. Kitzinger, L. Kelly and L. Regan, Young People's Attitudes Towards Violence, Sex and Relationships: A Survey and Focus Group Study (Zero Tolerance Charitable Trust: Edinburgh, 1998).

73 Temkin and Kraché, above n. 28.

74 Ibid. at 209.

75 J. C. Marsh, A. Geist and Nathan Caplan, Rape and the Limits of Law Reform (Auburn House Publishing: Boston, 1982) 85.

76 C. Spohn and J. Horney, Rape Law Reform: A Grassroots Revolution and Its Impact (Plenum Press: New York, 1992) 173 and see ch. 7 generally. 
before the legal changes will have their full impact ${ }^{\prime}{ }^{77}$ These findings further support the contention by the South African Law Reform Commission and preamble to the 2007 Act that effective law enforcement is reliant on factors that go far beyond the revision of legal rules and focus on what have been referred to as a 'second wave' of rape law reform. ${ }^{78}$

An issue that arises is the extent to which the South African legal process is also influenced by negative social attitudes. A 1995 Human Rights Watch report detailed many problems in the State response to rape and sexual assault in South Africa. It argued that the police 'often subscribe to stereotypes of raped women':

women face greater difficulty in filing rape charges if they did not resist physically, did not sustain serious injuries, did not act sufficiently distressed, dated the perpetrator, dressed 'provocatively'or are prostitutes. ${ }^{79}$

More recently, Smyth and Waterhouse claim that while South African police 'clearly recognize that rape and domestic violence are a reality, they just do not see that many cases fit their conceptions of these offences' ${ }^{80}$ The Human Rights Watch report also detailed judicial decisions which reflected 'sexist assumptions about women' and argued that 'Judges, magistrates and prosecutors all bring their own stereotypes to determinations of whether a woman has been raped'. ${ }^{81}$ For example, the report suggested that judges and prosecutors expected genuine rape victims to be physically injured. Further, some judges have suggested that the trauma suffered by a woman raped by man known to her would be 'ordinarily less' than in other cases. ${ }^{82}$ Evidence from the early $1990 \mathrm{~s}$ suggested that police believed that many allegations of rape were false, ${ }^{83}$ mirroring an international trend which indicates that police officers often wrongly label allegations of rape as false based on stereotypical attitudes regarding appropriate victim behaviour and reactions to rape. ${ }^{84}$ Other research suggests that some South African police officers actively seek out evidence regarding the reputation of rape complainants and

77 Home Office, Sexual Offences Act 2003: A Stocktake of the Effectiveness of the Act since Its Implementation (2006) para. 45.

78 I. Seidman and S. Vickers, 'The Second Wave: An Agenda for the Next Thirty Years of Rape Law Reform' (2005) Suffolk University Law Review 467. These suggested second wave reforms focus inter alia on complainant support and advice, monitoring the performance of law enforcement in their handling of rape cases and the availability of civil remedies.

79 Human Rights Watch, Violence Against Women in South Africa: State Responses to Domestic Violence and Rape (London, 1995) 91.

80 D. Smythe and S. Waterhouse, 'Policing Sexual Offences: Policies, Practices and Potential Pitfalls' in L. Artz and D. Smythe, Should We Consent? Rape Law Reform in South Africa (Juta: Cape Town, 2008) 211.

81 Above n. 79 at 98 and 103.

82 Ibid. at 104. Such views are widely held, but are also factually incorrect. See, e.g., L. Ellison and V. E. Munro, 'Reacting to Rape: Exploring Mock Jurors' Assessments of Complainant Credibility' (2009) 49 Brit J Criminology 202; P. Rumney, 'Progress at a Price: The Construction of Non-Stranger Rape in the Millberry Sentencing Guidelines' (2003) 66 MLR 880.

83 Jewkes and Abrahams, above n. 3, referring to S. Stanton, A Qualitative and Quantitative Analysis of Empirical Data on Violence Against Women in Greater Cape Town from 1989 to 1991, Institute of Criminology, University of Cape Town.

84 P. Rumney, 'False Allegations of Rape' (2006) 65 CLJ 128. 
rape allegations involving sexual partners will not even be investigated. ${ }^{85}$ In some cases victims who have reported to the police claim that officers exhibit disbelieving attitudes and that they are encouraged to withdraw their allegation. ${ }^{86}$

Police responses to rape are further complicated by other problems that have been identified within the literature: victims not being able to make a statement in her language of choice; ${ }^{87}$ the use of poor discretion in deciding what charge to lay (for example, rape or indecent assault); refusing to take down a statement unless a female officer is on duty; not proceeding with arrests or investigations; not allowing the victim privacy in making her statement; presenting incomplete statements; or not knowing the legal elements of the sexual offence and therefore not asking the right questions. ${ }^{88} \mathrm{~A}$ particular issue that arises in the context of South Africa is that of corruption involving criminal justice professionals. Research suggests that some reports of rape (known as 'dockets') are deliberately lost due to corruption. ${ }^{89}$ CIETafrica found:

All prosecutors and magistrates interviewed, as well as three quarters of all police respondents, agreed that there were opportunities for corruption in dealing with rape cases. When asked specifically if any of their cases had been mishandled due to corruption, one in three police said yes. ${ }^{90}$

There can be little doubt that work-based practices, the discretion vested in criminal justice professionals and the influence of rape myths and stereotypes are all factors that impact on the success of rape law reform. But judging and predicting the impact of the 2007 Act is a difficult task. In their research that examined the impact of rape law reform in six states in the USA, Spohn and Horney have pointed out that '[o]ur expectations concerning the impact of the reforms were complicated by the fact that the factors we see as related to impact interact with one another' ${ }^{91}$ They found that there was no consistent correlation between increased reporting, indictments and convictions in those states that had adopted 'strong reform', compared with those that had adopted weaker reforms. ${ }^{92}$ Given the scope of definitional, procedural and evidential legal reform in South Africa it is reasonable to describe theses reforms as 'strong', but as Spohn and Horney have found, this does not mean that they will necessarily have a significant impact on reporting, indictment and conviction rates. In this regard, one other point is worthy of mention. The South African reforms contain a number of measures relating to issues of definition, as well as evidential and procedural rules that are of particular importance to those cases that reach court. Yet, because of the process of attrition, most reports of rape never reach court-a point

85 Smythe and Waterhouse, above n. 80 at 210.

86 Ibid. at 211.

87 South Africa has 11 official languages.

88 L. Artz and D. Smythe, 'Case Attrition in Rape Cases: A Comparative Analysis' (2007) 20 SAJCJ 158, 168 and 179.

89 Jewkes and Abrahams, above n. 3 at 1232

90 CIETafrica, 1997-2000 surveys on sexual violence Summary Report 6.

91 Above n. 76 at 79.

92 Ibid. at 100-1. 
clear in the South African attrition statistics. ${ }^{93}$ Consequently, the benefit of these changes may be found in a relatively small number of cases.

\section{Conclusion}

Despite these findings, it should not be assumed that the South Africa reforms are pointless. Anachronistic and inappropriate legal codes cannot be defended and while many problems might remain, reform can be justified on many grounds, not least on the basis that the criminal law should provide for the coherent and fair labelling of criminal offences. In reality, the reform measures that have been adopted in South Africa are likely to form part of a longer-term process. It is likely that the South African experience of rape law reform will follow a similar pattern to that found in many other jurisdictions. There will be evaluation of the reforms and their effectiveness, further reform and a range of nonlegislative changes, including the training of criminal justice professionals and public education. ${ }^{94}$ To their credit, the South African Law Reform Commission and Parliament have, to varying degrees, recognised that law reform must be accompanied by a range of other nonlegislative measures. There must, however, be vigilance to ensure the effective evaluation and enforcement of the new reforms. 